\title{
Financial Efficiency of Islamic Business Unit at Regional Development Banks In Java Island
}

\author{
Eko Fajar Cahyono ${ }^{a}$ and Nisful Laila a \\ a Department of Economics And Business, Airlangga University, Indonesia
}

\begin{abstract}
Research on Islamic banks have grown rapidly, however, a special study on the regional development banks which belong to the local government. The purpose of this study was to determine the level of efficiency of sharia business unit's financial performance, regional bank development in Java Island, Indonesia. The method used is the Data Envelop Analysis with five banks and the period 2013 to 2015. The efficiency is an important factor in the development of a bank. Our results showed that the general level of efficiency sharia business unit Regional Development bank on the island of Java has achieved good efficiency, although there are some banks and a few years yet to achieve efficiency. The main factors that cause inefficiency bank among other operating costs and expenses for the results
\end{abstract}

Keywords: Efficiency, Data Envelope Analysis, Regional Development Banks

\section{INTRODUCTION}

Regional Development Bank (BPD) has three main functions, namely as (a) driving the creation of economic growth and regional development in order to improve society life quality, (b) holders of Regional Cash and or save Regional Money, and (c) a source of Local Revenue.

In carrying out its duties and functions, BPD seeks to raise public funds in the form of savings and channel them to the public in the form of credit or other forms.

Therefore, BPD has a strategic role in pushing the regional economy. It is believed that BPD can be more efficient than the other bank groups because BPD masters the operational network and filed condition in the regions. According to its function, the BPD operational area is more dominant in the regions.

Historically, BPD also has a very strong emotional bond with the communities in the regions. BPD was born, growing, becoming big, and interacting with people in the regions. A strong bond with governors, mayors and reagents as the proxy of shareholders also provides BPD high access to work on a captive market in the regions.

BPD is the motor in driving the pro-growth, pro-poor and projob programs through productive lending in the regions. Parts of BPD potentials have been already manifested. Of 26 BPDs operating in Indonesia, most of them have impressive performance.

The data from Bank Indonesia (BI) shows that the total assets of BPD in 2012 reached RP 395 trillion or number four after PT Bank Mandiri Tbk, PT Bank Rakyat Indonesia Tbk, and PT Bank Central Asia Tbk. In terms of efficiency, BPD is fairly efficient compared to national banks.

BPD has a ratio of operating expenses to operating income of approximately 74.17 percent, below the national commercial banks on average of 74.26 percent. BPD also still has the opportunity to encourage loan because the ratio of loan to deposit ratio (LDR) is still low, at 63.2 per cent.

No wonder that BI declared BPD as the bank regional champion in 2011. It means that BPD is directed to strengthen the regional economy, becoming the leading bank in the regions. BPD is expected to act as an agent of regional development in order to improve the small scale and micro credit to productive sectors of the industry.

In implementing its duties and functions, Regional Development Bank (BPD) also opens Islamic Business Unit (UUS) in dealing with the demands of Muslim consumers, so that Muslims in the regions can enjoy Islamic finance access more easily.

Efficiency and effectiveness are important to management because that is why managers are hired: to effectively and efficiently execute the agenda of the company for which they are employed. "Efficiency" refers to the manner in which work is conducted, generally discussed in terms of schedule. The less time it takes to accomplish the task in question, the more efficient the process. That is distinctly different from "effectiveness," which refers to the quality of the work performed. Concluding a task on time is great, but useless if the result is unsatisfactory. A manager is responsible for ensuring not just that schedules are met, but that the work is performed at or above the required level. Time, it is said in the world of business, is money. That means that an inefficient process is costing the company potential revenue because it is taking too much time to make the enterprise profitable.

It is estimated that the cost efficiency of Islamic Banks -using stochastic cost frontier approach, in Indonesia ${ }^{1}$. The samples of observation are three full Islamic banking system and 19 conventional banks listed on the Indonesia Stock Exchange (IDX) purposefully from $2004.03-2010.4$. The result showed that Islamic Banks are superior in the achievement of technical efficiency, but the average cost efficiency is much lower than

\footnotetext{
* ekofajarc@feb.unair.ac.id
} 
Conventional Banks. Cost inefficiency of Islamic-Banks come from allocation inefficiency.

Research on the regional development banks, especially in the Islamic business units are still rare to do. It is important to do research on a topic that topic.

\section{RESEARCH QUESTION}

How the efficiency of Islamic business units of regional development banks in Java?

\section{OBJECTIVE OF WRITING}

The objective of this scientific essay is to determine the efficiency level of financial performance in Islamic Business Unit of Regional Development Bank in Java. It is expected from this study that it will be found variables that work inefficiently and how higher the efficiency of these variables can be improved.

\section{DATA}

The data used in this research were secondary data obtained from financial statements of Banks. This study used a nonparametric quantitative method of Data Envelopment Analysis (DEA). The population is Syariah Bussiness Unit Regional Development Bank in Java Island. All population observed. Data taken from the financial statements of Islamic business units, regional development bank in the island of Java in the period 2013 to 2015. The Islamic business units include Bank DKI Jakarta, Bank Jateng, Bank Jatim, and Bank DIY (Yogyakarta).

\section{LITERATURE REVIEW}

\subsection{THE CONCEPT OF EFFICIENCY}

Definition of efficiency can be viewed from different angles. Efficiency can be defined as the ratio of input to output ${ }^{2}$. The three factors that most affect the efficiency, i.e. the state of the same input produces greater output, or with a same input produces greater output. Based on Toebin's opinion ${ }^{2}$, there are several things that affect the efficiency of the company. The first is economic arbitrage affect efficiency. Both accuracy to value assets, the third the company's ability to anticipate emerging risk and the fourth is concerned with efficiency is a payment made by a financial institution.

Viewed according to economic theory, appeared two terms of efficiency, i.e. the efficiency of technical and economic efficiency. Economic efficiency has an idea whose perspective is broader than the technical efficiency of micro-angle of view. The size of the technical efficiency is approached by means of technical and operational relationships in the process of transforming inputs into outputs.

Giufriida and Gravelle argued that there are three sources of inefficiency. Slightly output generated from a number of output so that the technique can lead to inefficiencies resulting output levels are far above the isoquant line or that the allocation inefficiency occurs when the input is used in the wrong proportions, so prices and productivity are on the borderline. Unit of economic activity remain on isoquant line, but at the wrong point. Lastly, scale inefficiency occurs when the total cost can be reduced by changing the amount of economic activity unit, and units of economic activities that are in line isoquant wrong ${ }^{2}$.

Efficiency is a measure of performance that is considered to underlie the entire performance of an organization. Philosophy efficiency is the ability to produce the optimum output with existing input, is a measure of expected performance. Thus there is a separation between the price and the unit used (input) as well as price and unit produced (output) in order to identify the allocation of inputs and outputs.

It is stated that the efficiency of a company is made up of two elements, namely technical efficiency and allocation efficiency $^{3}$. Technical efficiency indicates the company's ability to efficiently utilize the input to the optimum amount at the rate of input cost price at a given moment. These two components are then combined to produce a total measure of the efficiency or economic efficiency.

Economic efficiency has elements one of which is the technical efficiency, it is necessary for a technical efficiency of economic efficiency. In order to achieve the highest profit, the company must produce goods at optimal levels by using certain input optimal (technical efficiency) and by using a combination of inputs at cost price is right (allocation efficiency).The concept of measuring efficiency can be approached in two ways: on the input side and output Sisis. Two approaches are like two sides of a coin that cannot be separated.

Its input side approach is considered if a company uses two types of input, i.e., $\mathrm{xi}$ and $\mathrm{x} 2$, both are used to make one type of output $(\mathrm{y})$, this combination will produce output with Constant returns to scale (CRS) assumption. CRS assumption is that if the two types of inputs $\mathrm{x} 1$ and $\mathrm{x} 2$ the number is increasing continuously then output will also increase by the same percentage.

The concept of efficiency from the input side approach can be illustrated in the figure 1 :

From the picture above, the curve SS 'is an isoquant curve consisting of the set point company most efficient point in the set of fraternal (fully efficient firms) or consists of a lot of the company's most technically efficient. Companies that are at the point $\mathrm{P}$ is a company that is less efficient. The company is likely to be a company that is more efficient if he can reduce both types of inputs $\mathrm{x} 1$ and $\mathrm{x} 2$ to produce one unit of output so that the company is at a point $\mathrm{Q}$. The line between $\mathrm{P}$ and $\mathrm{Q}$ are potential improvement i.e. how much the number of inputs that can be reduced in order to achieve the level of efficiency in order to produce the same amount of output. The size of the technical efficiency of a company in a group of companions (TE) can generally be lowered by the ratio:

$\mathrm{TEI}=1-\mathrm{QP} / \mathrm{OP}=0 \mathrm{Q} / \mathrm{OP}(1)$

That $0<=\mathrm{TE},<=1$. TEI value $=1$ indicates that the company I was the most efficient technically between the allied groups.

Isocost line find the price ratio is the line AA 'between output 2 and input 1. Allocative Efficiency (AE) company first located at the point $P$, indicated by the ratio:

$\mathrm{AEI}=1-\mathrm{RQ} / 0 \mathrm{Q}=0 \mathrm{R} / 0 \mathrm{Q}(2)$

$\mathrm{RQ}$ can show where production is done at the point of extremely efficient technical SCARA namely Q, which can reduce production costs.tI is the company's economic efficiency is the product between allocative efficiency and technical efficiency mathematically

$\mathrm{EE}=\mathrm{TE} \times \mathrm{AEI}=(0 \mathrm{Q} / \mathrm{OP}) \times(0 \mathrm{R} / \mathrm{OQ})=0 \mathrm{R} / 0 \mathrm{R}(3)$

Where) $<=$, AE, EE, $<+1$.

In contrast to the input approach, output approach concentrating answer the question of how much quantity dalat output level in proportion to the quantity of the same input.

Assume a company has two types of outputs (y1 and y2) and one type of input $(\mathrm{X})$ in the draft CRS. Figure 2 below shows the concept of a measure of efficiency will approach the output side.

In the picture above, Curve Production Possibilities (PPF) is shown by the curve $\mathrm{ZZ}$ 'while the line indicated isorevenew line DD'. Point B is the point technically efficient while point inefficient shown at point A. Potential improvement possible is 
shown in the distance $A B$, it aims to improve the efficiency of the company. The size of technical efficiency to a company is $\mathrm{TEI}=1-\mathrm{AB} / \mathrm{OB}=0 \mathrm{~A} / \mathrm{OB}$ (4)

If you have any information on pricing outoput, the allocative efficiency can be calculated by the equation

$\mathrm{AEI}=1-\mathrm{BC} / 0 \mathrm{C}=0 \mathrm{~B} / 0 \mathrm{C}(5)$

Improvement to the point $\mathrm{C}$ has a meaning that companies in point $\mathrm{B}$ is still likely elevate its income by producing at the point of efficient both technically and allocative, namely point B'.

In general, economic efficiency is the product of technical efficiency and allocative efficiency, mathematically:

$\mathrm{EEI}=\mathrm{TE} \times \mathrm{AEI}=0 \mathrm{~A} / \mathrm{OB} \times 0 \mathrm{~B} / 0 \mathrm{C}=0 \mathrm{~A} / 0 \mathrm{C}(6)$

Size relative efficiency, good approach at the same input and output requires defining a boundary line that shows companies that are relatively efficient than fraternal groups.

\subsection{DATA ENVELOPE ANALYSIS}

DEA has been used in Contexts Including Several education systems, health care units, agricultural production, transport and military logistics including the banking sector ${ }^{4}$. The characteristic features DEA method is as follows:

a. Data used is homogeneous and is referred to as a decision making unit

b. An approach that is non-parametric

c. Is a part of a mathematical programming technique and can be transformed into linear programming models that can be solved with standard LP Solver.

d. Generates concept of a single input, single output, multiple inputs and multiple output

e. As an approach focused on frontiers instead of central tendencies

f. DEA capable determines the relative efficiency at a time over all other DMUs by finding the most favorable weights from the viewpoint of that target, DMU;

g. Alternative for making each inefficient DMU can be by projecting them onto the efficient frontier.

Since its introduction by Charnes in 1978, DEA method has been progressing rapidly and has been applied in various fields of science. DEA models are most often used is called the CCR models are named based on the creator that Charnes, Cooper and Rhodes, these models assume constant returns to scale (CSR). CSR Model produce own frontier production function. CCR has a frontier production model that contains a stretch of the existing linear combination of DMU. According to the DEA, models can be distinguished whether the goal-oriented input destination or output-oriented(Ie both minimize input for a particular output level or maximize output for a given level of input), this approach is given by Charnes, Cooper and Rhodes in 1978 followed by Farrell in 1957 technical efficiency measurement.

The notion that formal models assume that some few DMU to be evaluated was introduced in $2015^{4}$. Each DMU consume varying amounts of $\mathrm{m}$ different inputs to produce output is different. Specifically, DMUj use of $\mathrm{Xj}=[\mathrm{xij}]$ input $(\mathrm{i}=1 ; \ldots$; $\mathrm{m})$ and produced by $\mathrm{YJ}=[\mathrm{yrj}]$ output $(\mathrm{r}=1 ; \ldots ; \mathrm{s})$. sx n matrix output steps symbolized by $\mathrm{Y}$, and mxn matrix input steps denoted by X. Also, it can be assumed that xij $>0$ and yrj> 0 . Consider the problem to evaluate the relative efficiency of one of $\mathrm{n} \mathrm{DMU}$ to be identified as DMU0. efficiency relative to DMU0 calculated by considering the ratio of the weighted number of outputs to the weighted sum of inputs, subject to the constraint that no DMU can have a relative efficiency score is greater than one.

\section{FINDINGS}

Adv.Sci. Lett. y, xxxx-xxxx, 2017

\subsection{EFFICIENCY APPROACH AT BANKS}

\section{PREVIOUS STUDIES}

Some research have analysed of the extent level of efficiency of Islamic banking in Indonesia using the production approach and intermediation approaches. ${ }^{5}$ Here were the input and output variables used Table 1:

Table 1: Input and Output Specifications

Table 1: Input and Output Specifications
\begin{tabular}{|l|l|l|}
\hline \multicolumn{1}{|c|}{ Input } & Production Approach & Intermediation Approach \\
\hline $\mathrm{X}_{1}$ & Interest Cost & Labor Cost \\
\hline $\mathrm{X}_{2}$ & Personnel Cost & Fixed Assets \\
\hline $\mathrm{X}_{3}$ & Other Operating Cost & Third Party Fund \\
\hline Output & Production Approach & Intermediation Approach \\
\hline $\mathrm{Y}_{1}$ & Interest Revenue & Provided Loan \\
\hline $\mathrm{Y}_{2}$ & $\begin{array}{l}\text { Other } \\
\text { Revenues Operating }\end{array}$ & \\
\hline $\mathrm{Y} 3$ & & Other Revenues \\
\hline
\end{tabular}

Research on the bank owned by the government has been widely applied. One study compared the results of the efficiency of the bank owned by the government and the banks that are not owned by the government, and the result is a bank that is not owned by the government is more efficient than a bank owned by the government ${ }^{6}$. The research conducted in Vietnam by using a sophisticated methodology that DEA double bootstrap approach. The results also showed that banks with a large size are more efficient than small sized banks and banks with many branches numbering more efficient than the bank with fewer branch.

Research Islamic banks have also been much done ${ }^{7}$ to calculate the relative efficiency based on the perspective of regulators, consumers, managers, and stakeholders. Results showed that the banking sector is sensitive to economic changes. This paper hence aims to focus on Participation banks (PBS) or Islamic and conventional banks or deposit (DBs) in Turkey by examining Efficiencies in a comparative manner. This study compares the technical efficiency and scale efficiency. This study was conducted in $2007-2013$.

Not only was the Islamic bank efficiency research also covers an efficiency comparison between Islamic bank domestic and foreign Islamic bank. The study ${ }^{8}$ which contains Islamic banks in Malaysia, Indonesia, and Brunei in 2006 to 2014, using data envelope analysis as a measure of bank efficiency. The results of this study show that domestic bank is much more efficient than foreign banks. In accordance with the theory of home field advantage that domestic Islamic banks showed in the third measure of efficiency.

The efficiency of local banks is an interesting topic. The research ${ }^{9}$ estimated the cost efficiency and profits of local banks in China, this was done to evaluate the reform of the banking sector in the country. It used the foreign bank as a reference in the study of local banks as foreign banks are considered to have better competence in terms of organizational management, competencies at the global level as well as the application of more sophisticated technology. They found gradually domestic banks have caught up the cost advantage of foreign banks in a manner consistent with the increased competitive pressure. On the other hand, the profit advantage of domestic banks over foreign banks is widening. Not only banks in Muslim countries and banks in a third world country, bank efficiency research was also conducted in developed countries like Japan. Research ${ }^{10}$ revealed how the model is built to investigate the efficiency of the bank. Capital was formed by using the income approach to the environment 
is constructed as the difference between total revenue and the reserves for possible loan losses to incorporate the roles played by non-performing loans in bank production, then in next step is done inefficiency Applies Nerlove's revenue models. The timeframe of the study is 2000 to 2013 .

\section{RESEARCH METHODS}

In this study, the method used was Data Envelopment Analysis (DEA) by using Banxia Frontier Analyst 3 software. The advantage of this method was the possibility to measure the relative efficiency on the best value from the best producers in the sample.

\section{APPROACH USED}

There are various conceptual definitions in defining inputs and outputs in forming correct efficiency model. Concepts used to define the input and output relationship in the banking industry $^{11}$, namely;

1. Production Approach

This approach sees financial institution as a producer of deposit and loan accounts. Here the output is the amount of these accounts or of related transactions. Meanwhile, the input is the amount of labor, capital expenditure on fixed assets and other materials.

2. Intermediation Approach

It sees financial institution as an intermediary in financial services, which transforms and transfers, financial assets from surplus units to deficit units. In this case, inputs such as labor costs, capital and interest payments on deposits, and outputs measured are in the form of loans credit and financial investments

\section{ASSET APPROACH}

This approach sees the primary functions of a financial institution as a loan originator, approaching the intermediation approach, where output is actually defined in the form of assets.

In this study, the authors chose to use the production approach. Inputs and output variables used in this study were as follows:

Table 2: Research Variables and Data Sources

\begin{tabular}{|l|l|}
\hline \multicolumn{1}{|c|}{ Input Variables } & \multicolumn{1}{c|}{ Sources of Data } \\
\hline Wadiah Bonus, Expenses & Income Statements \\
\hline $\begin{array}{l}\text { Public \& Administration } \\
\text { Expenses }\end{array}$ & Income Statements \\
\hline Personnel Expenses & Income Statements \\
\hline Other Expenses & Income Statements \\
\hline \multicolumn{1}{|c|}{ Output Variables } & \multicolumn{1}{c|}{ Sources of Data } \\
\hline Murabahah Margin Revenues & Income Statements \\
\hline $\begin{array}{l}\text { Mudharabah Profit Sharing } \\
\text { Revenue }\end{array}$ & Income Statements \\
\hline Bonus Revenues & Income Statements \\
\hline Other Operating Revenues & Income Statements \\
\hline
\end{tabular}

\section{RESULTS AND DISCUSSION}

This study used the data from the Islamic Business Unit of Regional Development Bank On the Java Island, namely Bank DKI Jakarta, Bank Jateng (Central Java) from Central Java Province, Bank Jatim (East Java) from East Java Province, Bank DIY of Yogyakarta province, then Bank Jabar (West Java) Bantam could not be investigated due to a lack of data access. The time period of this study was 3 years ,i.e. 2013, 2014 and 2015. The data used in this research was derived from the official publication of Bank Indonesia, namely in the form of financial statements, especially the financial statements of income and balance sheet. This study used Banxia Frontier
Analysis software using DEA model. The selection of the method used was to maximize output (Table 3 and Table 4).

The research results show that 7 times of all research subjects have achieved efficiencies and 4 times the research unit cannot reach efficiency. UUS BPD Jatim has the highest efficiency level than other banks because for 3 consecutive years it has achieved efficiency. Meanwhile, UUS BPD DKI Jakarta and UUS BPD Jateng have the worst efficient level that is 2 consecutive years does not achieve efficiency.

Analysis on Factors Mostly Affecting Inefficiency at Every Bank

A. Islamic Business Unit (UUS) of BPD Jakarta

The factor mostly influences the inefficiency of UUS BPD DKI Jakarta in 2014 is administrative and general expenses as much as 99 percent. It is showed by figure 4 .

B. Islamic Business Unit (UUS) of BPD Jateng

The factor mostly influences the inefficiency of UUS BPD Jateng in 2014 is administrative and general expenses as much as 99 percent. It is showed by figure 5

C. Islamic Business Unit (UUS) of BPD Yogyakarta

Figures 6 showed Causes of Inefficiency at UUS BPD Yogyakarta

The factor mostly influences the inefficiency of UUS BPD DKI Yogyakarta in 2014 is administrative and general expenses as much as 99 percent. UUS BPD Jatim is not analyzed because it has been efficient.

Analysis of Inputs Orientation Efficiency Improvement Potential of Each Bank

If UUS BPD wants the efficiency, UUS BPD must meet the target column, and performs increase or decrease, while the factual condition is in the value column.

A. Islamic Business Unit (UUS) of Bank DKI Jakarta (Table 5)

B. Islamic Business Unit (UUS) of BPD Jateng (Table 6)

UUS BPD Jatim is not analyzed because it has been efficient.

C. Islamic Business Unit (UUS) of BPD YOGYAKARTA (Table 7)

\section{CONCLUSION}

The levels of efficiency of Islamic Business Unit (UUS) of BPD in Java Island vary, some have reached the efficient level and some have not reached yet the efficient level. Further efforts are necessary in order to achieve an optimum level of efficiency.

\section{References and Notes}

1. K. Pirzada, D. Wickramasinghe, G. A. Moens, A. F. Abdul Hamid, I. Zuhroh, M. Ismail and G. Maskie. Procedia - Social and Behavioral Sciences 211, (2015)

2. E. P. Lestari and A. Sutawijaya. Jurnal Ekonomi Pembangunan (2009)

3. Z. Abidin and E. Endri. Jurnal Akuntansi dan Keuangan 11, 1 (2010)

4. S. Bray, L. Caggiani and M. Ottomanelli. Transportation Research Procedia 5, (2015)

5. A. Ascarya and D. Yumanita. Buletin Ekonomi Moneter dan Perbankan 11, 2 (2008)

6. C. Stewart, R. Matousek and T. N. Nguyen. Research in International Business and Finance 36, (2016)

7. A. Yilmaz and N. Güneş. Procedia-Social and Behavioral Sciences 195, (2015)

8. F. Kamarudin, F. Sufian, F. W. Loong and N. A. M. Anwar. Future Business Journal 3, 1 (2017)

9. C. Hsiao, S. Yan and B. Wenlong. China Economic Review 35, (2015) 
RESEARCHARTICLE

10. H. Fukuyama and R. Matousek. European Journal of Operational Research 259, 2 (2017)

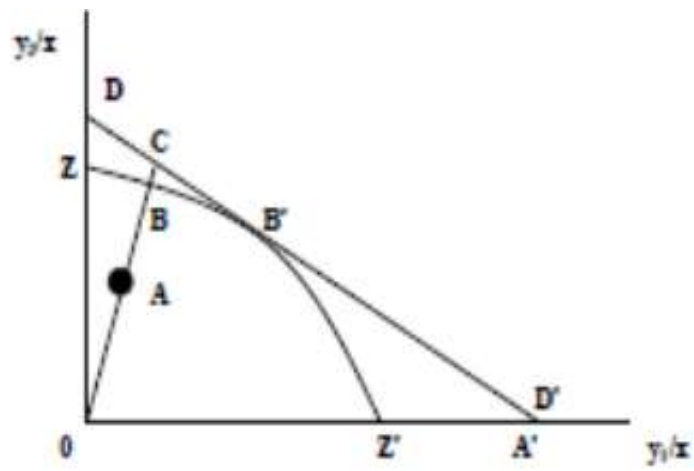

Fig.1. Concept efficiency of input side approach

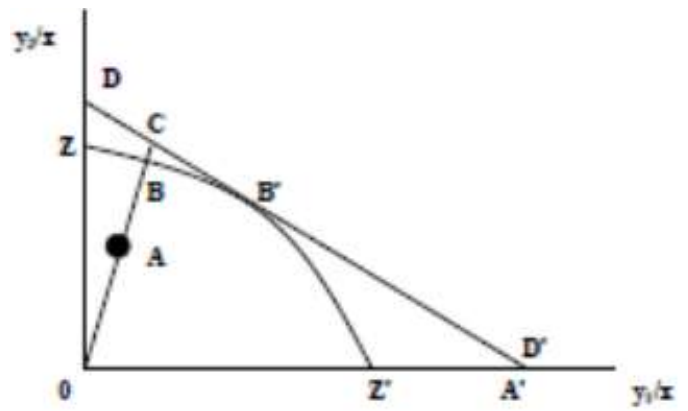

Fig.2. Concept efficiency with side output proxy

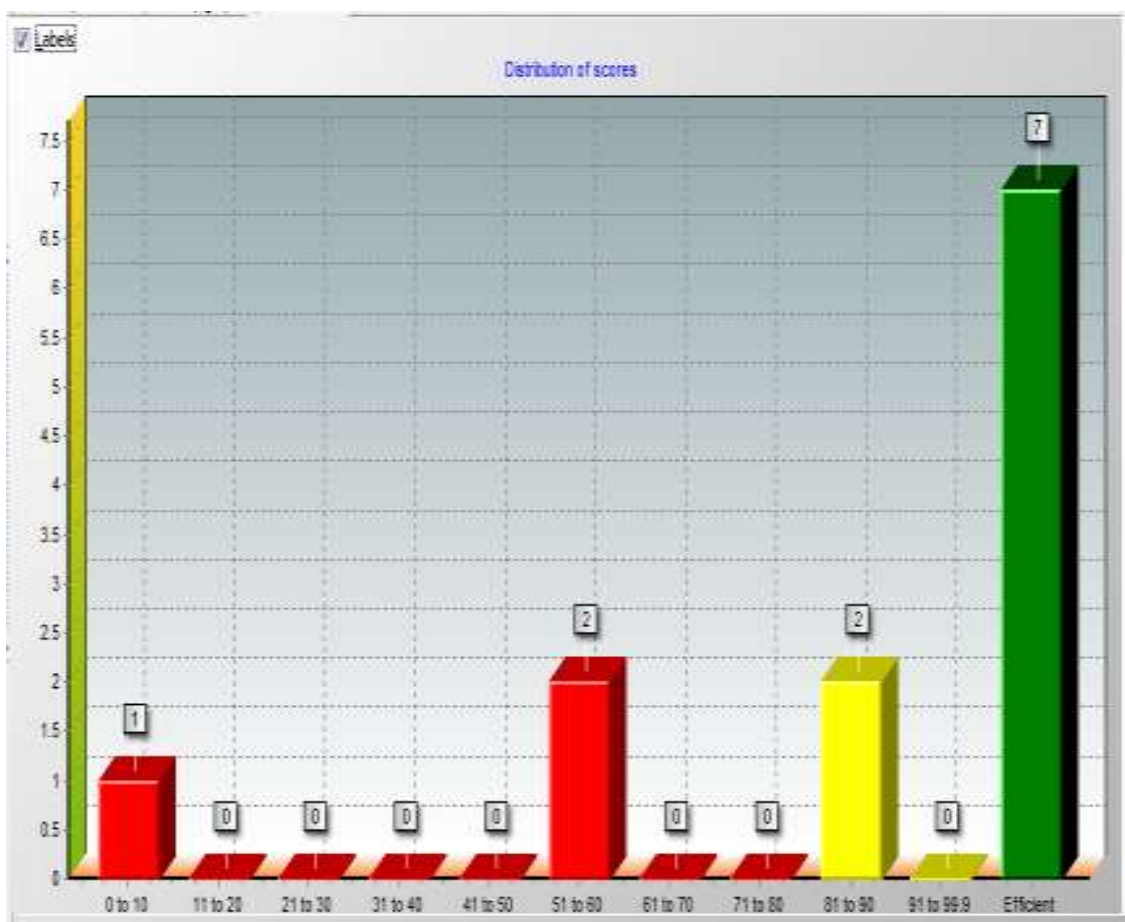

Fig.3. Distribution of Efficiency Scores of Islamic Business Unit (UUS) of BPD in Java Unit selection

\section{+ UUS BPD JAKARTA 2014}

Efficiency: $81.5 \%$

Input / Output Contributions

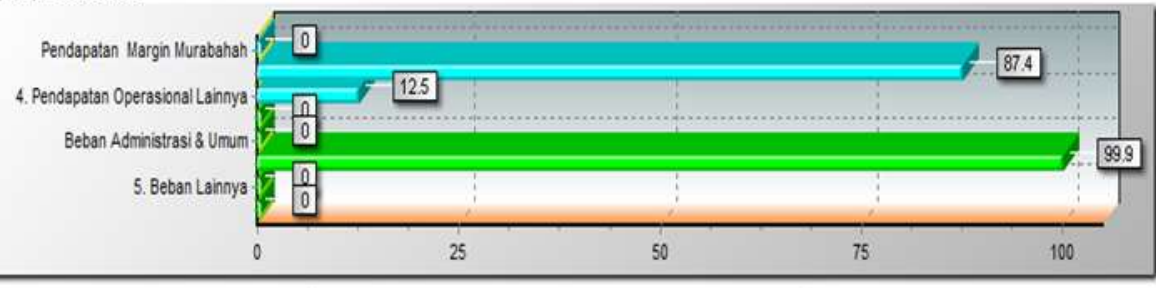

Fig.4. Causes of Inefficiency at UUS BPD Jakarta 


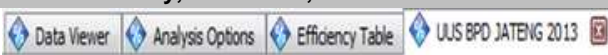

Unitseection

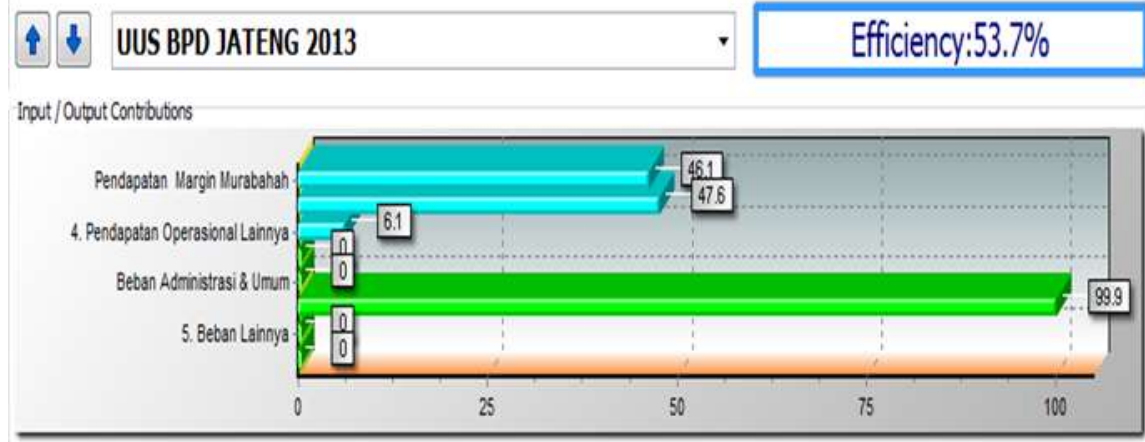

Fig.5. Causes of Inefficiency at UUS BPD Jateng

\section{Unt selection}

Input / Output Contrbutions

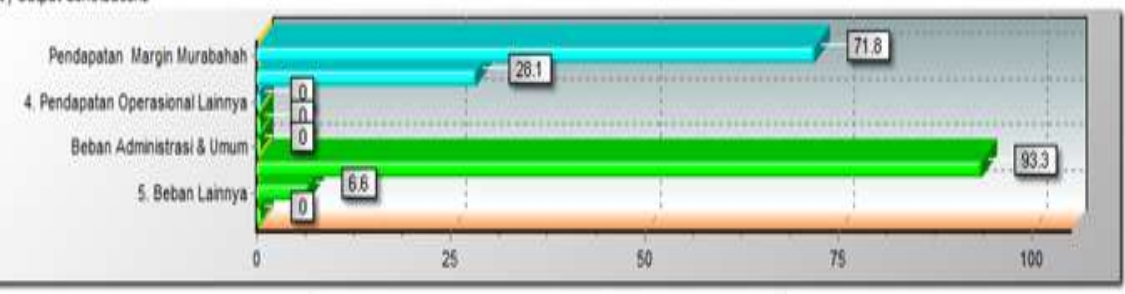

Fig.6.Causes of Inefficiency at UUS BPD Yogyakarta

Table 3: Output Results of Banxia Software

\begin{tabular}{|c|c|c|c|c|}
\hline Units & & Comparison 1 & & \\
\hline Unit name & Scor & & Efficient & Condition \\
\hline UUS BPD JAKARTA 2013 & & $83.7 \%$ & & 0 \\
\hline UUS BPD JAKARTA 2014 & & $81.5 \%$ & & $C$ \\
\hline UUS BPD JAKARTA 2015 & & $100,0 \%$ & $\vee$ & $\cap$ \\
\hline UUSS BPD JATENG 2013 & & $53.7 \%$ & & \\
\hline UUSS BPD JATENG 2014 & & $0.7 \%$ & & \\
\hline UUSS BPD JATENG 2015 & & $100,0 \%$ & $\vee$ & 0 \\
\hline UUSS BPD JATTM 2013 & & $100,0 \%$ & $\vee$ & 0 \\
\hline UUUS BPD JATTM 2014 & & $100,0 \%$ & $\vee$ & 0 \\
\hline UUS BPD JATIM 2015 & & $100,0 \%$ & $\vee$ & 0 \\
\hline UUS BPD YOGYAKARTA 2014 & & $56.8 \%$ & & \\
\hline UUUS BPD YOGYAKRTA 2013 & & $100,0 \%$ & $\vee$ & 0 \\
\hline UUSS BPD YOGYKARTA 2015 & & $100,0 \%$ & $\vee$ & $\cap$ \\
\hline
\end{tabular}

Table 4: Efficiency Table of Islamic Business Unit (UUS) of BPD in Java Island

\begin{tabular}{|c|l|c|c|c|}
\hline NO & Name of Units & Year & Scores & Description \\
\hline 1 & UUS BPD DKI JAKARTA & 2013 & 83.7 & Not efficient \\
\hline 2 & UUS BPD DKI JAKARTA & 2014 & 81,5 & Not efficient \\
\hline 3 & UUS BPD DKI JAKARTA & 2015 & 100 & Efficient \\
\hline 4 & UUS BPD JATENG & 2013 & 53,7 & Not efficient \\
\hline 5 & UUS BPD JATENG & 2014 & 0,7 & Not efficient \\
\hline 6 & UUS BPD JATENG & 2015 & 100 & Efficient \\
\hline 7 & UUS BPD JATIM & 2013 & 100 & Efficient \\
\hline 8 & UUS BPD JATIM & 2014 & 100 & Efficient \\
\hline 9 & UUS BPD JATIM & 2015 & 100 & Efficient \\
\hline 10 & UUS BPD YOGYAKARTA & 2013 & 56,8 & Not efficient \\
\hline 11 & UUS BPD YOGYAKARTA & 2014 & 100 & Efficient \\
\hline
\end{tabular}


Table 5: Potential Factors that can be improved to achieve efficiency in UUS BPD Jakarta

\begin{tabular}{|l|c|c|c|}
\hline Input/Output Name & Value & Target & Potential Improvement \\
\hline Mudharabah Profit Sharing Revenue & 11,021 & 22,70 & 105,54 \\
\hline Wadiah Bonus, Expenses & 5,29 & 0,74 & $-99,86$ \\
\hline Other Expenses & 741 & 14,98 & 97,96 \\
\hline Other Operating Revenues & 26.778 & 31.98 & 19,42 \\
\hline Personnel Expenses & 5.245 & 5.24 & 0.0 \\
\hline Murabahah Margin Revenues & 1,265 & 12,41 & 890,99 \\
\hline Public Administration Expenses & 827 & 0,87 & $99,83 \%$ \\
\hline
\end{tabular}

Table 6: Potential Factors that can be improved to achieve efficiency in UUS BPD Jateng

\begin{tabular}{|l|l|l|c|}
\hline Input/Output Name & Value & Target & Potential Improvement \\
\hline Mudharabah Profit Sharing Revenue & 3,672 & 6,84 & 86,32 \\
\hline Wadiah Bonus Expenses & 223 & 30,64 & $-86,26$ \\
\hline Other Expenses & 488 & 312,82 & $-35,90$ \\
\hline Other Operating Revenues & 4,4 & 8,20 & 86,32 \\
\hline Personnel Expenses & 1,851 & 1,65 & 0.0 \\
\hline Murabahah Margin Revenues & 3,04 & 5,66 & 86,32 \\
\hline Public Administration Expenses & 384 & 210,19 & $-45,26$ \\
\hline
\end{tabular}

Table 7: Potential Factors that can be improved to achieve efficiency in UUS BPD Yogyakarta

\begin{tabular}{|l|c|c|c|}
\hline Input/Output Name & Value & Target & Potential Improvement \\
\hline Mudharabah Profit Sharing Revenue & 5,465 & 9,53 & 76,15 \\
\hline Wadiah Bonus Expenses & 322 & 149,26 & $-53,65$ \\
\hline Other Expenses & 737 & 737 & 0 \\
\hline Other Operating Revenues & 1,771 & 5,76 & 225,45 \\
\hline Personnel Expenses & 3,449 & 3,45 & 0,00 \\
\hline Murabahah Margin Revenues & 7,396 & 13,03 & 76,15 \\
\hline Public Administration Expenses & 570 & 811,26 & $-16,73$ \\
\hline
\end{tabular}

